\section{The role of banking supervision in credit risk disclosures and loan loss provisions}

\author{
Daniela Albuquerque ${ }^{1}$ \\ ${ }^{1} I S E G$ - Lisbon School of Economics \& Management, University of Lisbon, \\ Management Department, Lisbon, Portugal. \\ Ana Isabel Morais ${ }^{2}$ \\ Inês Pinto ${ }^{2}$ \\ ${ }^{2}$ Advance/CSG, ISEG - Lisbon School of Economics \& Management; and \\ University of Lisbon, Management Department, Lisbon, Portugal.
}

\begin{abstract}
Purpose - The aim of this paper is to analyse the effect of the level of supervisory power on the level of disclosure of loan loss provisions and on the use of this item for income smoothing purposes.
\end{abstract}

Design/methodology/approach - Our sample includes 60 European banks from 15 countries, covering the period between 2012 and 2015. We use an index based on the measure of supervisory power and we estimate three regression models in order to investigate the role of banking supervision in credit risk disclosure and in the use of loan loss provisions for income smoothing purposes.

Findings - The results show that banks from countries with a higher level of supervisory power disclose more information about loan loss provisions. However, banks from countries with a higher level of supervisory power only disclose more information regarding Pillar 3 and not IFRS 7. Additionally, we conclude that managerial discretion is lower in banks domiciled in countries with high enforcement.

Originality/value - This study is useful for bank supervisors as it raises awareness about their influence on the disclosure of impairment losses on financial assets, and for users of financial statements as insights are provided about the relationship between supervisory power and income smoothing.

Keywords - loans loss provisions, bank supervision, income smoothing, Basel, credit risk.
Received on:

$06 / 19 / 2019$

Approved on:

$05 / 19 / 2020$

Responsible Editor:

Prof. Dr. Ilidio Lopes

\section{Evaluation process:}

Double Blind Review

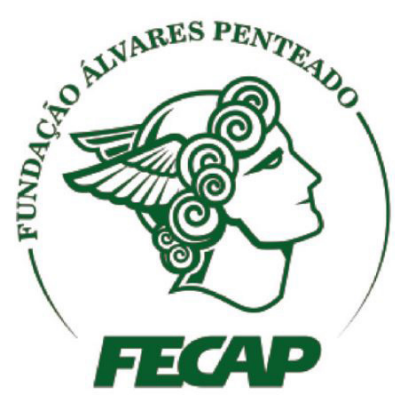

Revista Brasileira de Gestáo de Negócios 


\section{Introduction}

There has been much debate concerning the recognition, measurement, and disclosure of financial assets under international accounting standards and their role in the financial crisis of 2008 (Barth \& Landsman, 2010; Laux \& Leuz, 2010). The media has fiercely criticised the international accounting standards for how financial instruments allowed banks to under-provision the standards' main accrual item, loan loss provisions (LLPs). This under-provisioning concealed losses from shareholders and regulators until the borrower defaulted.

Bank supervision plays a major role in the accounting quality of banks. Despite the diverging objectives of regulation and accounting, banks' practices are shaped by both frameworks. The literature (Bikker \& Metzemakers, 2005; Bischof, 2009; Fonseca \& González, 2008; Gebhardt and Novotny-Farkas, 2018) has shown bank supervisors' influence on the quality of financial reporting and how country-specific circumstances with respect to the regulatory and supervisory environment affect banks' provisioning. Studies have explored two approaches to supervisory intervention in the measurement and treatment of LLPs: countries with stricter supervisory power and countries that do not intervene. In regimes with greater intervention by regulators, these studies report that supervisors require higher allowances for incurred losses beyond those allowed by the International Accounting Standard (IAS) 39 - Financial Instruments: Recognition \& Measurement to counteract the "too little, too late" issue. Additionally, these supervisors demand that banks provide additional disclosures on impairment losses. By contrast, non-interventionist supervisors do not interfere with loan loss provisions. The divergence of supervisory practices has always been a major issue within the European Union (EU). The Single Supervisory Mechanism (SSM) emerged as a response to the global financial crisis in 2014 and aimed to unify and improve banking supervision in Europe and, thus, to resolve the heterogeneity in supervisory practices across the EU.

The aim of this paper is to investigate the effect of the level of supervisory power on the level of disclosure of loan loss provisions and on the use of this item to smooth income. To this end, we hand-collected information from consolidated financial statements covering the period from 2012 to 2015 for 60 European banks from 15 different countries. We computed disclosure indexes in order to analyse compliance with the International
Financial Reporting Standards (IFRS) and Pillar 3 of the Basel accords. In a second stage, this study analyses the influence of supervisory power on the use of LLPs to smooth income (income smoothing hypothesis).

The results of the study show that banks domiciled in countries with greater enforcement present a significantly higher level of disclosure of loan loss provisions. However, when the level of disclosure is split into IFRS 7 - Financial Instruments: Disclosures and Pillar 3 disclosures, the results show that banks from countries with greater supervision only disclose more information to meet the Pillar 3 and not the IFRS 7 requirements. Therefore, we may conclude that different levels of supervision have different effects on compliance with risk disclosure requirements. Additionally, our results also confirm our second hypothesis by showing that income smoothing is lower in banks from countries with interventionist regulators. Finally, the findings provide evidence that after the launch of the SSM, there was an increase in income smoothing. This evidence is reflected in the inconsistency problems that may arise with the implementation of a supervision framework with two regulators.

This paper makes several contributions. First, the study is motivated by the lack of empirical literature on the link between banks' disclosure of LLPs and the supervisory framework. Although the literature on the relationship between recognising LLPs and the supervisory environment is extensive, the literature on the disclosure of LLPs, and in particular compliance with IFRS 7, is scarce. Bischof (2009) analyses the differences across countries of the effect of IFRS 7 on disclosure quality, but only for first time adopters. Second, this study is useful for bank supervisors as it raises awareness about their influence on financial assets through the disclosure of impairment losses and for users of financial statements as the study provides insights about the relationship between disclosure and earnings management. Third, it contributes to the debate about EU-wide inconsistency in the application of IFRS and Pillar 3 disclosure requirements that hinders the comparability of institutions' level of risk. Furthermore, this work also contributes to the debate on the possible consequences of the implementation of the SSM.

The remainder of the paper is structured as follows. Section 2 presents the background and the context of this study. In Section 3, we review the previous studies and formulate our hypotheses. We describe the sample, data, and research model in Section 4. Section 5 presents the research results, and Section 6 concludes the paper. 


\section{I.I Background and context}

The banking industry provides a unique setting to examine the role of supervisors in enforcing transparency in financial reporting for two main reasons. First, in this industry there are different entities responsible for the oversight and enforcement of accounting standards and disclosure requirements. The regulator of the national securities market and external auditors oversee the implementation of the IFRS accounting standards, while the banking supervisors focus on the enforcement of the Basel II/III regulations. To enhance and improve the consistency and comparability of these two disclosure regulations, the European Banking Authority (EBA) published guidelines on the revised requirements for Pillar 3 disclosures. Second, there are several differences in the regulatory powers of national banking supervisors. In some countries, bank regulators are even involved in setting the accounting standards (Gebhardt \& NovotnyFarkas, 2018).

Regarding the recognition and measurement of LLPs, international accounting standards required publicly-traded banks to apply IAS 39 between 2005 and 2017. IAS 39 requires the recognition of LLPs based on incurred losses. Thus, firms should only recognize a loan loss if there is objective evidence of one or more events that occurred after the initial recognition of the asset that result in an impairment loss (IAS 39, paragraph 59). With regard to disclosure requirements for LLPs, banks domiciled in countries that adopted IFRS and the Basel accords are required to apply both regulations to disclose information about LLPs. IFRS 7 has been in force since 2007, and all firms that hold financial instruments should comply with it. Basel III is based on three main pillars. Under Pillar 3, bank regulators have the responsibility to ensure that banks disclose sufficient information about the allocation of capital risk (Ozili \& Outa, 2017). While Pillar 3 requires more specific and technical information regarding capital requirements than IFRS 7, both regulations have many points in common regarding the disclosure of information, credit risk, liquidity risk, and market risk (Bischof, Daske, Elfers, \& Hail, 2016). In order to improve stability in the banking sector and to ensure the uniform application of Basel III in all member states, the EU established a supranational banking supervisory body (the SSM) in 2014. The SSM was a compromise to apportion power between the European Central Bank (ECB) and national supervisory authorities regarding bank supervision (Gren, Howarth, \& Quaglia, 2015). The establishment of the SSM reduced the flexibility of interventions by bank supervisors at the national level because it transferred to the ECB some of the national sovereignty of EU members with regard to banking supervision (1).

\section{I.2 Literature review and hypotheses development}

The literature has investigated the incremental value of additional information as a way to increase transparency and to reduce information asymmetries, not to mention as a tool for market discipline (Ahmed, Kilic, \& Lobo, 2006; Balakrishnan \& Ertan, 2018; Bischof, 2009). This strand of literature is even more relevant for the banking industry as the financial crisis of 2007-2008 is usually associated with its opacity because several banks took on excessive risks that were not properly disclosed (Goldstein \& Sapra, 2013).

Stephanou (2010) finds that the use of market discipline for prudential purposes has been more relevant in recent years as regulators have increasingly recognized its importance for market stability. The author argues that the disclosure of adequate, timely, and reliable information is fundamental for the market as banking problems are associated with principal-agent frictions that result from information asymmetries and inadequate contract enforcement. Iren, Reichert, and Gramlich (2014) conclude that there is a positive relationship between the quantity and quality of information disclosure and the performance and stability of banks.

In the banking industry, LLPs represent one of the largest expenses and reduce banks' profit and loss and capital (Jayaraman, Schonberger, \& Wu, 2019). LLPs are also relevant because they convey financial information about the future deterioration of credit risk.

The disclosure of LLPs plays a fundamental role in the market discipline framework because the cash flows and default risk of bank loans may have a significant impact on investors' estimates and therefore on stock market values (Wahlen, 1994). Based on the loan securitization market, Ertan, Loumioti, and Wittenberg-Moerman (2017) give evidence of how transparency can influence banks' credit practices and risk-taking, which leads to an improvement in the quality of securitized loans. Boland, Hogan, and Johnson (2018) reinforce the importance of 
mandatory disclosures, as they constitute an effective and low-cost regulatory device.

Supervision also plays a fundamental role in market discipline and banking stability. Stephanou (2010) shows that supervisory action and market discipline are complementary and that appropriate regulations can improve the disciplining power of markets. Therefore, we predict that different levels of supervisory power lead to different levels of market discipline.

The banking industry is particularly appropriate for studying the role of supervisors in enforcing transparency in financial reporting, as banking regulation involves multiple supervisory entities and the regulators' supervisory power is not uniform between countries. Bischof et al. (2016) provide evidence that the heterogeneity in regulatory supervision may influence firms' disclosure behaviour, which in turn may have an impact on capital markets. The authors find that firms disclose more information about risk in countries where the banking regulator has more supervisory powers.

Although there are many studies on the importance of disclosure, there are few that address the role of supervision in the disclosure of LLPs (Bischof et al., 2016). Unlike Bischof et al. (2016), who focus on several disclosures related to financial instruments (capital adequacy, credit risk, market risk, securitization and operational risk), we focus on credit risk disclosures.

Considering the heterogeneity in the supervision of banking regulations in Europe (Barth, Caprio, \& Levine, 2013), we state the following hypothesis:

H1: The level of disclosure of LLPs is higher in banks domiciled in countries with stricter supervision.

There is a wide consensus in the literature that managers in the banking sector use LLPs to manipulate earnings to reduce income volatility: the income-smoothing hypothesis (Ahmed, Takeda, \& Thomas, 1999; Anandarajan, Hasan, \& McCarthy, 2007; Leventis, Dimitropoulos, \& Anandarajan, 2011).

Several studies analyse the relationship between the nature and degree of supervision and the quality of financial reporting, and they provide evidence that stronger supervisory regimes are associated with less earnings management and higher quality financial reporting. Bouvatier, Lepetit, and Strobel (2014) conclude that the use of LLPs to smooth earnings is less pronounced in countries with stricter supervisory regimes or higher quality external audits. Using a sample from 41 countries, Fonseca and González (2008) show that income smoothing decreases in line with restrictions on bank activities and official and private supervision. Using a set of banking data, Gunther and Moore (2003) find that supervisory examinations lead to a significant number of adverse revisions to financial statements, which is evidence that additional regulatory rules may contribute to market discipline. Costello, Granja and Weber (2016) show that greater regulatory enforcement leads to higher transparency in financial reporting, as measured by the likelihood of restatements of regulatory reports.

However, Curcio, De Simone, and Gallo (2017) draw attention to a potential unwitting side effect on financial reporting of stricter supervision. Using the EBA 2010 and 2011 stress tests, the authors show that the disclosure of sensitive information may create incentives for managers to use their discretion to manage earnings in order to improve the market's perception of their banks' risk.

Dal Maso, Kanagaretnam, Lobo, and Terzani (2018) provide evidence that bank regulation complements the effect of accounting enforcement on the earnings quality of banks. Regarding the predictive ability of LLPs, Marton and Runesson (2017) conclude that the local GAAP, which generally allows more judgement-based models, performs better in stricter enforcement settings.

Therefore, and considering that less regulatory enforcement of transparency in financial reporting for the banking system is usually associated with the instability in the financial system of 2007 and 2008 (Costello et al., 2016), we state the following hypothesis:

$\mathrm{H} 2$ : Income smoothing is lower in banks domiciled in countries with stricter supervision.

\section{Research Design and Sample}

\section{I Sample selection}

The sample was taken from the list of significant supervised entities compiled by the ECB (https://www. bankingsupervision.europa.eu/banking/list/who/html/index. en.html). On 4 September 2014, the ECB published its last list of significant supervised entities and less significant institutions for the purposes of the Eurozone's SSM.

Of the 120 entities presented in this list, subsidiaries of parent banks located outside the EU were eliminated to avoid biases arising from the impact of their national enforcement institutions. This elimination affected 21 banks. Subsidiaries of parent banks that were themselves 
included in the sample (11 banks) were also excluded in order not to double-count certain disclosure policies. Disclosures of a subsidiary in a different country are likely to be affected by the supervisory activities in the home country of the parent bank, which would bias the observations for the subsidiary's country if they were included in the sample. Banks that were removed from the initial list and banks that were included afterwards were also excluded to guarantee a uniform analysis. Banks that do not apply IFRS for the period under analysis were also excluded. Fifteen banks were also eliminated because financial statements were not available in English or due to a lack of information in the sample period. Finally, banks founded after 2012 or that were in liquidation during the analysis period were not considered. Table 1 shows our final sample with a total of 60 banks from 15 different European countries. The data and disclosure policies were hand-collected from the financial statements available in English for the period from 2012 to 2015.
We use an index (SPOWER) to analyse the impact of the role and power of supervisory entities in the disclosure and recognition of LLPs. This index is based on the measure of supervisory power developed by Barth et al. (2013) and is used in the literature as a proxy for the level of banking supervision (Dal Maso et al., 2018; Fonseca \& González, 2008; Gebhardt \& Novotny-Farkas, 2011; Marton \& Runesson, 2017). We elaborate this index based on the World Bank Database 2012 (https://www.worldbank.org/en/ research/brief/BRSS, recovered on 8 June, 2020) on bank regulation and supervision (Barth et al., 2013). The index ranges from 0 to 17 as it includes 14 questions on enforcement powers (Part 11 - Enforcement of the World Bank survey) and 3 questions about accounting and information disclosure of the bank regulation and supervision. These three questions are: Are banks required to submit their financial statements to the banking supervisor prior to public disclosure? Do banks disclose off-balance sheet items to the supervisors? And

Table 1.

\section{Sample selection}

\begin{tabular}{|c|c|c|}
\hline & \multicolumn{2}{|c|}{ Panel A: Total Sample } \\
\hline & \multicolumn{2}{|l|}{$\mathrm{N}^{\text {os }}$ of Banks } \\
\hline Initial banks (ECB list) & \multicolumn{2}{|l|}{120} \\
\hline - subsidiaries of banks located outside EU & \multicolumn{2}{|l|}{21} \\
\hline - subsidiaries of banks included in the sample & \multicolumn{2}{|l|}{11} \\
\hline - banks that do not apply IFRS & \multicolumn{2}{|l|}{4} \\
\hline - banks with missing data & \multicolumn{2}{|l|}{15} \\
\hline - banks founded after 2012 or in liquidation & \multicolumn{2}{|l|}{7} \\
\hline - others & \multicolumn{2}{|l|}{2} \\
\hline Total & \multicolumn{2}{|l|}{60} \\
\hline \multirow{2}{*}{ Countries: } & \multicolumn{2}{|c|}{ Panel B: Sample by Country } \\
\hline & No of Banks & $\%$ \\
\hline Austria & 3 & $5.00 \%$ \\
\hline Belgium & 4 & $6.67 \%$ \\
\hline Cyprus & 1 & $1.67 \%$ \\
\hline Finland & 1 & $1.67 \%$ \\
\hline France & 5 & $8.33 \%$ \\
\hline Germany & 11 & $18.33 \%$ \\
\hline Greece & 4 & $6.67 \%$ \\
\hline Ireland & 3 & $5.00 \%$ \\
\hline Italy & 9 & $15.00 \%$ \\
\hline -Luxembourg & 1 & $1.67 \%$ \\
\hline Malta & 1 & $1.67 \%$ \\
\hline Netherland & 4 & $6.67 \%$ \\
\hline Portugal & 3 & $5.00 \%$ \\
\hline Slovenia & 2 & $3.33 \%$ \\
\hline Spain & 8 & $13.33 \%$ \\
\hline Total & 60 & $100.00 \%$ \\
\hline
\end{tabular}


do supervisors require banks to publicly disclose other information not required by the financial reporting standards (e.g., prudential reports)? These questions are associated with greater supervisory power regarding enforcement and accounting disclosure. The higher the index, the greater the supervisory power. Table 2 shows the level of supervisory power as measured through the index described above for each country. Finland has the lowest level of supervisory power (SPOWER $=58.82 \%$ ), while Malta registers a score of $100 \%$. The following countries have a SPOWER score below the sample mean: Austria, Belgium, Finland, Greece, Ireland, and Spain.

\subsection{Methodology}

\subsection{Role of banking supervision in LLP disclosure}

In the first stage of our work, we study the influence of supervisory power on LLP disclosure. With this aim in view, we estimate the following regression model over the period from 2012 to 2015:

Table 2.

\section{Level of supervisory power by country (SPOWER index)}

\begin{tabular}{lr}
\hline \multicolumn{1}{c}{ Countries: } & SPOWER \\
\hline Austria & $70.59 \%$ \\
Belgium & $76.47 \%$ \\
Cyprus & $88.24 \%$ \\
Finland & $58.82 \%$ \\
France & $94.12 \%$ \\
Germany & $82.35 \%$ \\
Greece & $76.47 \%$ \\
Ireland & $64.71 \%$ \\
Italy & $88.24 \%$ \\
Luxembourg & $94.12 \%$ \\
Malta & $100.00 \%$ \\
Netherland & $88.24 \%$ \\
Portugal & $82.35 \%$ \\
Slovenia & $88.24 \%$ \\
Spain & $76.47 \%$ \\
Mean & $81.96 \%$ \\
\hline
\end{tabular}

Note. SPOWER is an index based on the measure of supervisory power developed by Barth et al. (2013), which ranges from 0 to 17 based on the survey by the World Bank Database 2012 on bank regulation and supervision. The higher the index, the greater the supervisory power.
DISCINDEX $=\beta_{0}+\beta_{1}$ SPOWER $+\beta_{2}$ SIZE $+\beta_{3} E B T+$ $\beta_{4} L O A N S+\beta_{5} \Delta L O A N S+\beta_{6} G D P+\beta_{7} D S S M+\varepsilon$

DISCINDEX is a self-constructed disclosure index that measures a bank's compliance with the requirements of IFRS 7 (IFRS7INDEX), Pillar 3 (PILLAR3INDEX), or with both (TOTALINDEX) for LLPs (Appendix A). The index is constructed by assigning a score of one to the different disclosure items required under IFRS 7 and Pillar 3 and dividing by the sum of the applicable items. Therefore, DISCINDEX measures the level of disclosure of LLPs and ranges from 0 to $100 \%$ (full compliance). It is an unweighted disclosure index as all items in it have the same weight and are equally important (Hossain, 2008; Kolar \& Falež, 2018).

The SPOWER variable is an index based on the measure of supervisory power developed by Barth et al. (2013). This index ranges from 0 to 17.

We include a set of control variables that may influence the level of disclosure of LLPs. SIZE is the natural log of a bank's total assets. The literature provides evidence that larger firms disclose more information as their stakeholders are more demanding regarding the level of disclosures (Carcello, Hermanson, \& Neal, 2002). EBT is the ratio of earnings before loan loss provisions and taxes to total assets. Some studies present mixed results regarding the relationship between firm performance and disclosure, which indicates managers can be selective in their disclosures (Lang \& Lundholm, 1993; El-Gazzar, Fornaro, \& Jacob, 2008). LOANS is the ratio of customer loans to assets. This variable is used as a proxy for the general component of LLPs that increases generic banks' reserves and so is the component that can be discretionally used by managers (Curcio et al., 2017). $\triangle$ LOANS is the loan growth in year $t$. This variable is expected to be positively associated with bank risk. According to Laeven and Majnoni (2003), a prudent bank should have a positive association between the amount of loan loss provisions and loan growth. Therefore, we expect a positive impact of $\triangle \mathrm{LOANS}$ on the level of disclosure. GDP is the annual growth rate of the gross domestic product for each country and is used as a proxy of economic growth (Anandarajan et al., 2007) and changes in risk ratings García, Monte-Mor and Tardin (2019). DSSM is a dummy variable that equals one for the period between 2014 and 2015, which is the period after the launch of the SSM. We have included this variable for two reasons. First, 2014 was the year when the SSM entered into force. 
Second, the EU required that new regulations ${ }^{1}$ based on Basel III that introduced changes to supervisors' power be in effect on 1 January 2014.

\subsubsection{Role of banking supervision in income smoothing}

In the second stage of our study, we analyse the influence of banking supervisory power on the use of LLPs to smooth income. For this analysis, we apply a model based on a modified version of the model used by Ahmed et al. (1999), Anandarajan et al. (2007), Curcio and Hasan (2015), Leventis et al. (2011), Ozili and Arun (2018), and Pinto and Picoto (2018):

$$
\begin{aligned}
& L L P_{i t}=\alpha_{0}+\beta_{1} L L P_{i t-1}+\beta_{2} E B T_{i t}+\beta_{3} C A P_{i t}+ \\
& \beta_{4} N P L_{i t}+\beta_{5} L O A N S_{i t}+\beta_{6} S I Z E_{i t}+\beta_{7} G D P_{i t}+\varepsilon_{i t}
\end{aligned}
$$

LLP is the ratio of LLPs to total loans. EBT is the ratio of earnings before taxes and LLPs to total assets. A positive relationship between EBT and LLPs indicates the existence of earnings management through income smoothing (Ahmed et al., 1999). As there is evidence that the disturbances in the regression models have serial correlation (Bikker \& Metzemakers, 2005), a lagged dependent variable is included in the models as an explanatory variable. CAP is the ratio of actual regulatory capital (primary or Tier I capital) before loan loss reserves to the minimum required regulatory capital. This variable is included in order to control for capital management. If bank managers use LLPs for the purpose of managing capital adequacy ratios, then there should be a negative coefficient between CAP and LLPs (Anandarajan et al., 2007). To evidence the discretionary component of LLPs, the variables NPL (nonperforming loans) and LOANS are included in the model (Curcio \& Hassan, 2015). NPL is the ratio of nonperforming loans to total assets in order to capture specific provisions that banks set aside for actual loan losses (Ozili \& Arun, 2018). As specific provisions increase with loan losses, we expect a positive relationship between NPL and LLP. LOANS is the ratio of customer loans to assets. This variable is used as a proxy to capture general provisions (Curcio \& Hasan, 2015). LOANS should be positively related to LLPs as it indicates the credit risk of the overall portfolio (Bouvatier et al., 2014).

1 Directive 2013/36/EU and Regulation (EU) 575/2013.
Other control variables are considered in the model: SIZE is the natural logarithm of total assets to control for bank size; and GDP is the annual growth rate of the gross domestic product for each country and is used as a proxy for economic growth. According to Ozili and Arun (2018), the coefficient for GDP should be negative as LLPs are higher during recessions and lower during upturns.

To determine whether there is a difference in earnings management between banks located in a country with greater supervisor control, we include SPOWER in the model as a proxy for the level of supervisory power:

$L L P_{i t}=\alpha_{0}+\beta_{1} L L P_{i t-1}+\beta_{2} E B T_{i t}++\beta_{3} C A P_{i t}+\beta_{4} N P L_{i t}+\beta_{5} L O A N S_{i t}$

$+\beta_{6} S I Z E_{i t}+\beta_{7} G D P_{i t}+\beta_{8} S P O W E R_{i t}+\beta_{9} S P O W E R * E B T_{i t}+\varepsilon_{i t}$

Following Bouvatier et al. (2014), Laeven and Majnoni (2003), and Ozili and Arun (2018), we introduced a lag of the dependent variable (LLP) to estimate our model through an OLS as our sample is too small for GMM estimators (Roodman, 2009).

\subsection{Descriptive statistics}

Table 3 presents some descriptive statistics regarding both models.

For the full sample, LLPs represent an average of $1.6 \%$ of total loans, which is evidence of the importance of this bank accrual. In line with the nature of the business, customers' loans are about $59 \%$ of total assets in the full sample. EBT is on average $0.6 \%$ for the full sample. With regard to the Tier 1 ratio, the full sample presents an average ratio of $12.5 \%$, which is well above the minimum required by both Basel II and III. The mean level of the supervisory index is $81.7 \%$, with the lowest score being 58.8\% for Finland and the highest being 100\% for Malta.

Table 4 shows the Pearson correlations between SPOWER and the different variables. A higher level of supervisory power is negatively associated with the level of LLPs, nonperforming loans, and loan growth. All the correlation values are below 0.5 , which indicates there are no multicollinearity concerns in our tests.

\section{Results}

\section{I The role of banking supervision in LLP disclosure}

Figure 1 shows the evolution of the IFRS7 and PILLAR3 indexes between 2012 and 2015. 
Table 3.

Descriptive statistics

\begin{tabular}{lccccc}
\hline & Mean & Median & Standard Deviation & Min & Max \\
\hline TOTALINDEX & 0.728 & 0.733 & 0.162 & 0.267 & 0 \\
PILLAR3INDEX & 0.542 & 0.600 & 0.334 & 0.5 & 1 \\
IFRS7INDEX & 0.856 & 0.875 & 0.113 & 0.588 & 1 \\
SPOWER & 0.817 & 0.823 & 0.083 & 0 & 0.257 \\
LLP & 0.016 & 0.008 & 0.0249 & -0.093 & 0.056 \\
EBT & 0.006 & 0.007 & 0.012 & 0 & 0.905 \\
CAP & 0.125 & 0.060 & 0.120 & 0 & 0.610 \\
NPL & 0.084 & 0.046 & 0.102 & 0.176 & 0.886 \\
LOANS & 0.587 & 0.618 & 0.160 & 1.160 & -0.950 \\
SLOANS & -0.008 & -0.025 & 0.159 & 9.628 & 12.318 \\
SIZE & 11.147 & 11.116 & 0.593 & -0.073 & 0.251 \\
GDP & 0.009 & 0.007 & 0.0361 & & \\
\hline
\end{tabular}

Note. All variables are defined in Appendix B.

Table 4.

\section{Correlation matrix}

\begin{tabular}{|c|c|c|c|c|c|c|c|c|c|}
\hline & SPOWER & LLP & EBT & CAP & NPL & LOANS & $\triangle$ LOANS & SIZE & GDP \\
\hline SPOWER & 1 & & & & & & & & \\
\hline LLP & $-0.09^{*}$ & 1 & & & & & & & \\
\hline EBT & 0.01 & 0.06 & 1 & & & & & & \\
\hline CAP & -0.01 & -0.03 & -0.09 & 1 & & & & & \\
\hline NPL & $-0.12^{* *}$ & $0.38^{* * *}$ & 0.06 & 0.04 & 1 & & & & \\
\hline LOANS & 0.00 & -0.06 & -0.05 & 0.01 & $0.235^{* * *}$ & 1 & & & \\
\hline$\triangle$ LOANS & -0.034 & $-0.175^{* * *}$ & 0.08 & -0.01 & 0.02 & 0.02 & 1 & & \\
\hline SIZE & $0.12^{* *}$ & $-0.29^{* * *}$ & $-0.27^{* * *}$ & -0.05 & $-0.35^{* * *}$ & 0.00 & ${ }^{*} 0.11$ & 1 & \\
\hline GDP & $-0.13^{* *}$ & $-0.27^{* * *}$ & -0.09 & 0.01 & $-0.11^{* *}$ & 0.0171 & -0.06 & -0.03 & 1 \\
\hline
\end{tabular}

Note. All variables are defined in Appendix B. ${ }^{* *},{ }^{* *}$, and ${ }^{\star}$ denote significance at the $1 \%, 5 \%$, and $10 \%$ levels.

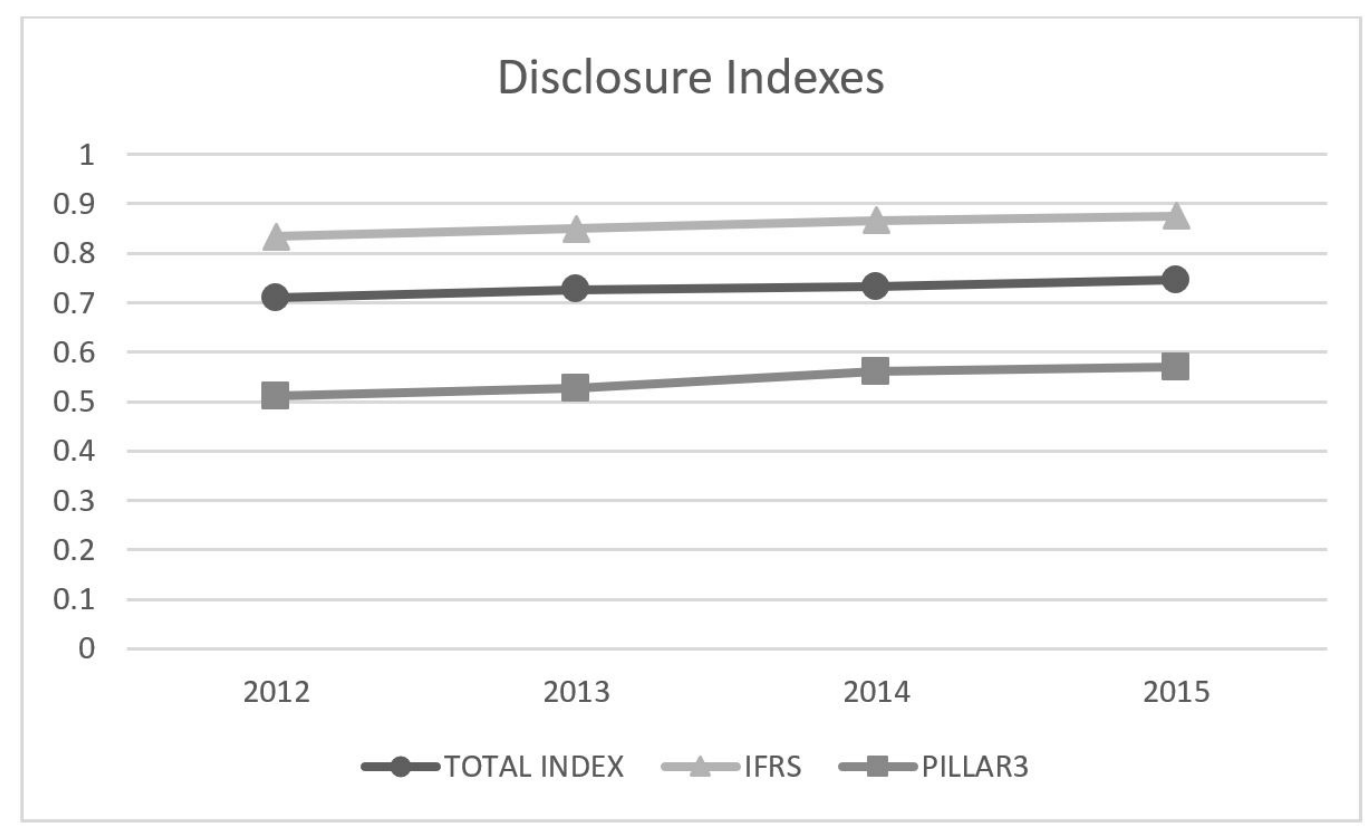

Figure 1. This figure plots the time-series of the TOTALINDEX, IFRS7, and PILLAR3 indexes. 
We observe that the evolution of both the IFRS7 and PILLAR3 indexes is very stable over time, with a slight increase after 2014, mainly regarding PILLAR3, which coincides with the entry into force of the SSM.

Table 5 presents the results of the analysis of the impact of the level of supervisory power on LLP disclosure.

The findings indicate that for banks from countries with greater supervisory power, the disclosure indexes are higher in the case of the TOTALINDEX and PILLAR3 disclosure requirements. We do not confirm this evidence regarding IFRS7 disclosure requirements as the coefficient $\beta_{1}$ is not statistically significant in this case. In line with the results of Bischof et al. (2016), our findings confirm that the national banking regulator plays a key role in the enforcement of risk disclosures, especially for the Basel accords requirements. Additionally, the findings show that the level of disclosure increases after 2014, although this variable is not statistically significant in the model. The finding is evidence that the SSM has a positive impact on the transparency of financial reporting.

As expected, the results show that LOANS are positively related with the disclosure of information about LLPs as it is a general component of LLPs (Curcio et al., 2017).

Using the index developed by Brown, Preiato, and Tarca (2014) to measure the differences between countries in relation to the auditing of financial statements and the enforcement of compliance with each country's accounting standards, we did additional tests to verify the impact of accounting enforcement on disclosure indexes. Untabulated findings show that, unlike what we find with
DISCINDEX, countries with higher scores for accounting enforcement register less disclosure regarding Pillar 3. The association with IFRS7 and the TOTALINDEX is not statistically significant. This result may be because this index aims to capture the differences between countries in relation to the institutional setting for financial reporting, specifically the auditing of financial statements according to the Basel accords.

Table 6 shows the results regarding the role of banking supervision in income smoothing.

The results do not provide evidence of income smoothing in our sample as $\beta_{2}$ is not statistically significant. This result may be influenced by the fact that our sample includes countries with a high level of supervisory power.

With regard to the control variables, the coefficient for CAP is not statistically significant in model (1). There is no evidence of capital management. After several changes in the regulation on capital adequacy, several studies have found no association between LLPs and capital management (Curcio \& Hasan, 2015; Leventis et al., 2011). As expected, the NPL coefficent is positive and statistically significant at the $5 \%$ level across the majority of estimations. Higher nonperforming loans mean higher LLPs. The GDP coefficient is negative, which is evidence that in periods of economic growth LLPs are lower (Laeven \& Majnoni 2003; Leventis et al., 2011; Ozili, 2018). The other control variables are not statistically significant. The coefficient for the lagged LLP variable is positive and statistically significant, which indicates the adjustment of LLPs is gradual (Bouvatier et al., 2014).

Table 5.

\section{Regression analysis of the role of banking supervision in LLP disclosure}

\begin{tabular}{|c|c|c|c|c|c|c|c|c|}
\hline \multirow{2}{*}{ Variables: } & \multirow{2}{*}{ Coefficient } & \multirow{2}{*}{$\begin{array}{c}\text { Predicted } \\
\text { Sign }\end{array}$} & \multicolumn{2}{|c|}{ TOTALINDEX } & \multicolumn{2}{|c|}{ IFRS7INDEX } & \multicolumn{2}{|c|}{ PILLAR3INDEX } \\
\hline & & & Coefficient & $P$-Value & Coefficient & $P$-Value & Coefficient & P-Value \\
\hline Intercept & $\beta_{0}$ & $?$ & 0.331 & $(0.155)$ & $0.685^{* * *}$ & $(0.000)$ & -0.428 & $(0.364)$ \\
\hline SPOWER & $\beta_{1}$ & + & $0.260^{* *}$ & $(0.021)$ & 0.088 & $(0.286)$ & $0.550^{* *}$ & $(0.018)$ \\
\hline SIZE & $\beta_{2}$ & + & 0.016 & $(0.387)$ & 0.008 & $(0.496)$ & 0.046 & $(0.228)$ \\
\hline EBT & $\beta_{3}$ & $?$ & $-3.023^{*}$ & $(0.059)$ & -1.055 & $(0.399)$ & $-5.522^{*}$ & $(0.069)$ \\
\hline LOANS & $\beta_{4}$ & + & $0.019^{* * *}$ & $(0.000)$ & 0.000 & $(0.968)$ & $0.045^{* * *}$ & $(0.000)$ \\
\hline$\triangle$ LOANS & $\beta_{5}$ & + & -0.105 & $(0.107)$ & -0.072 & $(0.148)$ & -0.101 & $(0.334)$ \\
\hline GDP & $\mathrm{B}_{6}$ & - & $0.464^{*}$ & $(0.084)$ & 0.338 & $(0.123)$ & 0.725 & $(0.309)$ \\
\hline DSSM & $\mathrm{B}_{7}$ & + & 0.011 & $(0.609)$ & 0.019 & $(0.222)$ & 0.031 & $(0.515)$ \\
\hline No of Observations & & & 240 & & & 240 & & 240 \\
\hline $\operatorname{Adj}-R^{2}$ & & & $9.06 \%$ & & & $5.02 \%$ & & $8.28 \%$ \\
\hline
\end{tabular}

Note. This table presents the results of the following equation:

DISCINDEX $=\beta_{0}+\beta_{1} S P O W E R+\beta_{2} S I Z E+\beta_{3} E B T+$

$\beta_{4} L O A N S+\beta_{5} \triangle L O A N S+\beta_{6} G D P+\beta_{7} D S S M+\varepsilon$. All variables are defined in Appendix B. ${ }^{* *}$, ${ }^{* *}$, and ${ }^{*}$ denote significance at the $1 \%, 5 \%$, and $10 \%$ levels. 
Table 6.

Results for the income-smoothing hypothesis

\begin{tabular}{|c|c|c|c|c|c|c|}
\hline \multirow{2}{*}{ Variables: } & \multirow{2}{*}{ Coefficient } & \multirow{2}{*}{ Predicted Sign } & Coefficient & \multirow{2}{*}{$P$-Value } & Coefficient & \multirow{2}{*}{$P$-Value } \\
\hline & & & Model 1 & & Model 2 & \\
\hline Intercept & $\beta_{0}$ & $?$ & $0.112^{*}$ & $(0.064)$ & 0.032 & $(0.276)$ \\
\hline $\operatorname{LLP}_{\mathrm{t}-1}$ & $\beta_{1}$ & $?$ & $0.176^{*}$ & $(0.059)$ & $0.232^{* *}$ & $(0.021)$ \\
\hline EBT & $\beta_{2}$ & + & -0.616 & $(0.167)$ & $8.847^{* *}$ & $(0.022)$ \\
\hline CAP & $\beta_{3}$ & - & -0.002 & $(0.384)$ & $-0.003^{*}$ & $(0.089)$ \\
\hline NPL & $\beta_{4}$ & + & $0.066^{* * *}$ & $(0.009)$ & $0.067^{* * *}$ & $(0.007)$ \\
\hline LOANS & $\beta_{5}$ & + & -0.004 & $(0.777)$ & 0.000 & $(0.980)$ \\
\hline SIZE & $\beta_{6}$ & + & $-0.008^{*}$ & $(0.095)$ & $-0.009^{*}$ & $(0.052)$ \\
\hline GDP & $\beta_{7}$ & - & $-0.149^{* * *}$ & $(0.000)$ & $-0.103^{* * *}$ & $(0.002)$ \\
\hline SPOWER & $\beta_{8}$ & + & & & $0.115^{* *}$ & $(0.032)$ \\
\hline SPOWER*EBT & $\beta_{9}$ & - & & & $-11.701^{* *}$ & $(0.023)$ \\
\hline Dummy Year & & & yes & & Yes & \\
\hline No of Observations & & & 240 & & 240 & \\
\hline Adj-R ${ }^{2}$ & & & $36.00 \%$ & & $43.77 \%$ & \\
\hline
\end{tabular}

Note. This table presents the results of the following equation: $L L P_{i t}=\alpha_{0}+\beta_{1} L L P_{i t-1}+\beta_{2} E B T_{i t}++\beta_{3} C A P_{i t}+\beta_{4} N P L_{i t}+\beta_{5} L O A N S_{i t}+\ldots$ All

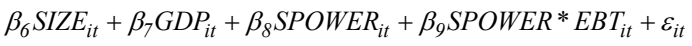

variables are defined in Appendix B. Models are estimated using pooled OLS with the lag value of LLP and with P-values. ***, **, and * denote significance at the $1 \%, 5 \%$, and $10 \%$ levels.

In order to test for differential income smoothing by banks according to the level of supervisory power, we add to our baseline model the SPOWER variable, which measures the level of supervisory power for each county. In model (2), the coefficient for EBT is positive and statistically significant, meaning that the association between EBT and LLPs is positive, which is evidence of income smoothing. Nevertheless, the coefficient $\beta_{9}$ is negative and statistically significant, showing lower discretion in banks domiciled in countries with stricter supervision, which is in line with Bouvatier et al. (2014) and Fonseca and González (2008). We may conclude that income smoothing is lower in banks that are domiciled in countries with stronger enforcement, which confirms our second hypothesis. Thus, the effectiveness of supervision may be influenced by the heterogeneity still existing in the structure and powers of banking supervision entities (Bischof et al., 2016).

\subsection{Further issues}

\subsection{The influence of the Single Supervisory Mechanism on income smoothing}

The principal aim of the SSM is to ensure efficient and harmonized European regulation and supervision of banks. Accordingly, the launch of this entity in 2014 has led to a reduction in the heterogeneity of national supervisory authorities (NSAs) with the transfer of supervisory powers from the national to the supranational level (Fiordelisi, Ricci, \& Lopes, 2017). Although an increase in harmonization among supervisory entities should contribute to an increase in the quality of financial reporting, the reduction in NSAs' powers could also lead to a decline in the level of regulation and enforcement at the national level. Therefore, the impact of the SSM could have conflicting effects on managerial reporting in relation to the level of income smoothing. To test the influence of the launch of the SSM on the quality of financial reporting, we have added to our base model the dummy variable DSSM, which equals one for the post-SSM period (2014-2015). Then, we interact DSSM with the EBT variable in order to investigate if there are any differences in managerial discretion after the implementation of the mechanism. The results are presented in Table 7. The coefficient for DSSM*EBT is positive and statistically significant at the $1 \%$ level, which indicates that there is an increase in income smoothing after the launch of the SSM. This evidence may be explained by a decline in the supervisory power in some more interventionist countries and the supervision of banks directly by the 
Table 7.

Influence of the Single Supervisory Mechanism and LLP disclosure on income smoothing

\begin{tabular}{|c|c|c|c|c|c|c|c|c|}
\hline \multirow[t]{2}{*}{ Variables: } & \multirow[t]{2}{*}{ Coefficient } & \multirow{2}{*}{$\begin{array}{l}\text { Predicted } \\
\text { Sign }\end{array}$} & \multirow{2}{*}{$\begin{array}{c}\begin{array}{c}\text { Coefficient } \\
(P \text {-Value })\end{array} \\
(1)\end{array}$} & \multirow[t]{2}{*}{$P$-Value } & \multirow{2}{*}{$\begin{array}{c}\begin{array}{c}\text { Coefficient } \\
(P-\text { Value })\end{array} \\
(2)\end{array}$} & \multirow[t]{2}{*}{$P$-Value } & \multirow{2}{*}{$\begin{array}{c}\begin{array}{c}\text { Coefficient } \\
(P \text {-Value })\end{array} \\
(3)\end{array}$} & \multirow[t]{2}{*}{$P$-Value } \\
\hline & & & & & & & & \\
\hline Intercept & $\beta_{0}$ & $?$ & 0.104 & $(0.130)$ & $0.100^{*}$ & $(0.083)$ & $0.098^{* *}$ & $(0.018)$ \\
\hline $\operatorname{LLP}_{\mathrm{t}-1}$ & $\beta_{1}$ & ? & $0.162^{*}$ & $(0.092)$ & $0.182^{* *}$ & $(0.028)$ & $0.161^{*}$ & $(0.059)$ \\
\hline $\mathrm{EBT}^{\mathrm{lit}}$ & $\beta_{2}$ & + & $-0.720^{* * *}$ & $(0.001)$ & -0.068 & $(0.671)$ & -0.320 & $(0.287)$ \\
\hline CAP & $\beta_{3}$ & - & -0.001 & $(0.487)$ & -0.002 & $(0.295)$ & -0.001 & $(0.578)$ \\
\hline NPL & $\beta_{4}$ & + & $0.063^{* *}$ & $(0.044)$ & $0.065^{*}$ & $(0.055)$ & $0.068^{* * *}$ & $(0.009)$ \\
\hline LOANS & $\beta_{5}$ & + & -0.002 & $(0.850)$ & -0.001 & $(0.886)$ & -0.003 & $(0.800)$ \\
\hline SIZE & $\beta_{6}$ & + & -0.007 & $(0.187)$ & -0.007 & (0.119) & $-0.007^{* *}$ & $(0.041)$ \\
\hline GDP & $\beta_{7}$ & - & $-0.149^{* *}$ & $(0.017)$ & $-0.147^{* *}$ & $(0.025)$ & $-0.156^{* * *}$ & $(0.000)$ \\
\hline DSSM & $\beta_{8}$ & + & -0.006 & $(0.131)$ & - & & & \\
\hline DSSM*EBT & $\beta_{9}$ & - & $0.528^{* * *}$ & $(0.011)$ & - & & & \\
\hline DPILLAR3AM & $\beta_{10}$ & $?$ & & & $0.010^{* *}$ & $(0.028)$ & & \\
\hline DPILLAR3AM*EBT & $\beta_{11}$ & + & & & $-0.780^{* * *}$ & $(0.006)$ & & \\
\hline DIFRS7AM & $\beta_{12}$ & $?$ & & & & & 0.0142 & $(0.378)$ \\
\hline DIFRS7AM*EBT & $\beta_{13}$ & + & & & & & -1.291 & $(0.372)$ \\
\hline Dummy Year & & & No & & Yes & & Yes & \\
\hline No of Observations & & & 240 & & 240 & & 240 & \\
\hline $\operatorname{Adj}-R^{2}$ & & & $36.26 \%$ & & $37.99 \%$ & & $39.53 \%$ & \\
\hline
\end{tabular}

$$
L L P_{i t}=\alpha_{0}+\beta_{1} L L P_{i t-1}+\beta_{2} E B T_{i t}++\beta_{3} C A P_{i t}+\beta_{4} N P L_{i t}+\beta_{5} L O A N S_{i t}+
$$

Note. This table presents the results of the following equation: $\beta_{6} S I Z E_{i t}+\beta_{7} G D P_{i t}+\beta_{8} D S S M_{i t}+\beta_{9} D S M M * E B T_{i t}+\beta_{10} P I L L A R 3 A M_{i t}+$. All

$$
\beta_{11} \text { PILLAR3AM*EBT }{ }_{i t}+\beta_{12} I F R S 7 A M_{i t}+\beta_{13} I F R S 7 A M * E B T_{i t} \varepsilon_{i t}
$$

variables are defined in Appendix B. Regressions using GMM estimators are not presented considering the small sample period. ${ }^{* * *}, * *$, and ${ }^{*}$ denote significance at the $1 \%, 5 \%$, and $10 \%$ levels.

ECB. Further research on the impact of the SSM on financial reporting quality is needed as the launch of the SSM led to supervision at two levels, which could cause supervisory inconstancies (Fiordelisi et al., 2017).

\subsubsection{The influence of the LLP disclosure on income smoothing}

The literature provides evidence of the benefits of additional information to the quality of financial reporting because of less information asymmetry and greater market discipline (Ahmed et al., 2006; Balakrishnan \& Ertan, 2018; Bischof, 2009). Nevertheless, with regard to banks' stress test results, Goldstein and Sapra (2013) suggest that there are potential endogenous costs associated with such disclosure as it can induce suboptimal behaviour in banks. Curcio et al. (2017) provide evidence that the disclosure of detailed sensitive information can be associated with higher discretionary use of LLPs in order to improve the market's perception of bank risk.

In order to investigate the influence of the LLP disclosure on income smoothing, we add DPILLAR3AM and DIFRS7AM, which are dummy variables that equal one if the company registers a PILLAR3 or IFRS7 index above the sample median PILLAR3 and IFRS7 disclosure index, respectively. The results are presented in Table 7.

With regard to the PILLAR3 index, the coefficient for the interaction of DPILLAR3AM and EBT is negative and statistically significant at the $1 \%$ level. This result indicates that the disclosure of additional information about LLPs contributes to a decrease in the use of LLPs to smooth income. The same does not occur with respect to the IFRS7 index, as the coefficient for DIFRS7AM*EBT is not statistically significant. These findings may be explained by the differences that exist among supervisory entities and the regulations on LLP disclosures. While the enforcement of IFRS 7 is generally ensured by the national securities markets and applies to all firms subject to mandatory IFRS reporting, Pillar 3 enforcement lies under the supervision of the national banking regulator. Thus, assuming that with respect to banks, the bank regulator plays an important role in monitoring to enhance transparency, Pillar 3 disclosures on LLPs should contribute positively to improving the quality of financial reporting through a decrease in 
income smoothing. Regarding the control variables, the coefficients for NPL and GDP maintain the predicted sign as in the previous results.

\section{Conclusions}

This study examines the role of supervisors in the disclosure of impairment losses on one specific type of financial asset - the loans to and receivables from customers. The findings show that the level of supervisory power only positively influences the disclosure of Pillar 3 requirements on LLPs but has no impact regarding IFRS 7 requirements. The fact that there are different entities responsible for the oversight and enforcement of accounting standards and Basel requirements may contribute to some inconsistency in the supervision of the banking sector. We can conclude that different supervisors and different enforcement mechanisms may influence the effectiveness of supervision (Bischof et al., 2016)

The study further analysed the relationship between banks' supervision and income smoothing as the regulatory supervision framework has an influence on the quality of financial reporting. The study shows lower income smoothing by banks in countries with a greater level of supervisory power. Our results support the importance of interventionist supervision in reducing income smoothing and increasing the quality of banks' financial statements.

The paper makes theoretical and practical contributions. This study contributes to the scarce literature about the disclosure of LLPs and its link with the supervisory framework. It also contributes to the debate about the implementation of the SSM and about the inconsistency in the application of IFRS and Pillar 3. The study also makes practical contributions: for bank supervisors it raises awareness about their influence on the disclosure of impairment losses on financial assets; and for users of financial statements the study provides insights about the relationship between disclosure and earnings management.

The main limitations of this study are the sample size, the imbalance in the distribution of the sample by country, the short period analysed, and the collection method. The results may be influenced by an imbalance since three countries (Germany, Italy, and Spain) represent almost half of the sample. On the other hand, we use the same disclosure index throughout the study period, although some changes could occur regarding the level of supervisory power. Nevertheless, the information to control for such changes was not available. Although equations (2) and (3) include a lag variable of LLP, we do not estimate the income smoothing model through Blundell and Bond's (1998) system GMM as our sample is small in time and countries and can therefore lead to biased estimators (Roodman, 2009). An analysis of all the EU banks in the periods before, during, and after the 2008 financial crisis would be an interesting approach. Future research could also include other control variables, such as the composition of the board of directors. A better understanding of the relationship between the different entities that require disclosures and their interactions would also be of interest. On the other hand, the accounting and regulatory frameworks are now more aligned with the new forward-looking provisioning model. IFRS 9 - Financial Instruments, which is the accounting standard that superseded IAS 39, requires the incorporation of information about future expected credit losses in provisioning and an earlier recognition of loan losses. This additional information, in turn, has extended the disclosure requirements and should contribute to the transparency in the process of loan loss accounting. Nonetheless, Novotny-Farkas (2016) warns that the widened scope for managerial judgement gives a critical role to IFRS 7 regarding market discipline, which can potentially affect a consistent application of IFRS 9 across credit institutions and the comparability of credit institutions' financial statements. To guarantee the adequacy, relevance, and comparability of disclosures, the EBA issued guidelines on the best practices for credit risk management and accounting for expected credit losses in May of 2017, which built on the Basel Committee on Banking Supervision (BCBS) guidance. All these transformations in the accounting and regulatory structures are expected to lead to a more harmonized banking framework regarding the recognition and disclosure of LLPs. Therefore, it would be pertinent to study whether national differences prevail under IFRS 9, the revised version of Pillar 3, and the ECB's continuous efforts to guarantee a uniform supervisory approach.

\section{Acknowledgements}

We are gratefully acknowledge financial support from FCT- Fundação para a Ciencia e Tecnologia (Portugal), national funding through research grant UIDB/04521/2020 


\section{References}

Ahmed, A. S., Takeda, C., \& Thomas, S. (1999). Bank loan loss provisions: A reexamination of capital management, earnings management and signaling effects. Journal of Accounting and Economics, 29(1), 1-25.

Ahmed, A. S., Kilic, E., \& Lobo, G.J. (2006). Does recognition versus disclosure matter? Evidence from value-relevance of banks' recognized and disclosed derivative financial instruments. Accounting Review, 81(3), 567-588.

Anandarajan, A., Hasan, I., \& McCarthy, C. (2007). Use of loan provisions for capital, earnings management and signalling by Australian banks. Accounting and Finance, 47, 357-379.

Balakrishnan, K. \& Ertan, A. (2018). Banks' financial reporting frequency and asset quality. Accounting Review, 93(3), $1-24$.

Barth, J.R., Caprio, G. \& Levine, R. Jr. (2013). Bank regulation and supervision in 180 countries from 1999 to 2011. Journal of Finance Economic Policy, 5(2), 111-219.

Barth, M. \& Landsman, W. (2010). How did financial reporting contribute to the financial crisis?. European Accounting Review, 19(3), 399-423.

Bikker, J. A. \& Metzemakers, P. A. J. (2005). Bank provisioning behavior and procyclicality. Journal of International Financial Markets, Institutions and Money, 15(2), 141-157.

Bischof, J. (2009). The effects of IFRS 7 adoption on bank disclosure in Europe. Accounting in Europe, 6 (2), 167-194.

Bischof, J., Daske, H., Elfers, F., \& Hail, L. (2016). A tale of two regulators: Risk disclosures, liquidity, and enforcement in the banking sector. SSRN Electronic Journal. Retrieved from https://papers.ssrn.com/sol3/ papers.cfm?abstract_id=2580569

Blundell, R. \& Bond, S. (1998). Initial conditions and moment restrictions in dynamic panel data models. Journal of Econometrics, 87(1), 115-143.
Boland, C. M., Hogan, C. E., \& Johnson, M. F. (2018). Motivating compliance: Firm response to mandotory disclosure policies. Accounting Horizons, 32(2), 103-119.

Bouvatier, V., Lepetit, L., \& Strobel, F. (2014). Bank income smoothing, ownership concentration and the regulatory environment. Journal of Banking \& Finance, 41, 253-270.

Brown, P., Preiato, J., \& Tarca, A. (2014). Enforcement of accounting standards: An audit and enforcement proxy. Journal Finance \& Accounting, 41(1-2), 1-52.

Carcello, J., Hermanson, D. \& Neal, T. (2002). Disclosures in audit committee charters and reports. Accounting Horizons, 16(4), 291-304.

Costello, A., Granja, J. \& Weber, J. (2019). Do strict Regulators increase the transparency of the banking system? Journal of accounting research, 57(3), 603-636.

Curcio, D., \& Hasan, I. (2015). Earnings and capital management and signaling: The use of loan-loss provisions by European banks. European Journal of Finance, 21(1), 26-50.

Curcio, D., De Simone, A., \& Gallo, A. (2017). Financial crisis and international supervision: New evidence on the discretionary use of loan loss provisions at Euro Area commercial banks. British Accounting Review, 49(2), 181-193.

Dal Maso, L., Kanagaretnam, K., Lobo, G. J., \& Terzani, S. (2018). The influence of accounting enforcement on earnings quality of banks: Implications of bank regulation and the global financial. Journal of Accounting and Public Policy, 37(5), 402-419.

El-Gazzar, S. M., Fornaro, J. M., \& Jacob, R.A. (2008). An examination of the determinants and contents of corporate voluntary disclosure of management's responsibilities for financial reporting. Journal of Accounting, Auditing \& Finance, 23(1), 95-114.

Ertan, A., Loumioti, M., \& Wittenberg-Moerman, R. (2017). Enhancing loan quality through transparency: Evidence from the european central bank loan level 
reporting initiative. Journal of Accounting Research, 55(4), 877-918.

Fiordelisi, F., Ricci, O. \& Lopes F.S.S. (2017). The unintended consequences of the launch of the single supervisory mechanism in Europe. Journal of Financial and Quantitative Analysis, 52(6), 2809-2836.

Fonseca, A.R. \& González, F. (2008) Cross-country determinants of bank income smoothing by managing loan loss provisions. Journal of Banking \& Finance, 32 (2), 217-228.

García, R., Monte-Mor, D. \& Tardin, N. (2019). Can accounting-based and market-based indicators predict changes in the risk rating of brazilian banks?. Revista Brasileira de Gestão de Negócios, 21(1), 152-168.

Gebhardt, G. \& Novotny-Farkas, Z. (2011). Mandatory IFRS adoption and accounting quality of European banks. Journal of Business Finance \& Accounting, 38(34), 289-333.

Gebhardt, G., \& Novotny-Farkas, Z. (2018). Comparability and predictive ability of loan loss allowances: The role of accounting regulation versus bank supervision. (Working paper n. 591). Retrieved form: https://ssrn. com/ abstract_id=3174016

Goldstein, I. \& Sapra, H. (2013). Should banks'stress test results be disclosed? An analysis of the costs and benefits. Foundations and Trends in Finance, 8(1), 1-54.

Gren, J., Howarth, D. \& Quaglia, L. (2015). Supranational banking supervision in Europe: The construction of a credible Watchdog. Journal of Common Market Studies, 53(1), 181-199.

Gunther, J. \& Moore, R. (2003). Loss underreporting and the auditing role of bank exams. Journal of Financial Intermediation, 12(2), 153-177

Hossain, M. (2008). The extent of disclosure in annual reports of banking companies: The case of India. European Journal of Scientific Research, 23(4), 599-680.

Iren, P., Reichert, A. K. \& Gramlich, D. (2014). Information disclosure, bank performance and bank stability. International Journal of Banking, Accounting and Finance, 5(4), 374-417.

Jayaraman, S., Schonberger, B. \& Wu, J. (2019). Good buffer, bad buffer: Smoothing in banks' loan loss provisions and the response to credit supply shocks. Journal of Law, Finance, and Accounting, 4(2), 183-238.

Kolar, I. \& Falež, N. (2018). The level of disclosure in annual reports of banks: The case of Slovenia. Organizacija, 51(4), 311-325.

Laeven, C. \& Majnoni, G. (2003). Loan loss provisioning and economic slowdowns: Too much, too late?. Journal of Financial Intermediation, 12(2), 178-197.

Lang, M. H., \& Lundholm, R. J. (1993). Cross-sectional determinants of analyst ratings of corporate disclosures. Journal of Accounting Research, 31(2), 246-271.

Laux, C. \& Leuz, C. (2010). Did fair-value accounting contribute to the financial crisis?. Journal of Economic Perspectives, 24(1), 93-118.

Leventis, S., Dimitropoulos, P. E., \& Anandarajan, A. (2011). Loan loss provisions, earnings management and capital management under IFRS: The case of EU commercial banks. Journal of Financial Services Research, 40, 103-122.

Marton, J. \& Runesson, E. (2017). The predictive ability of loan loss provisions in banks: Effects of accounting standards, enforcement and incentives. The British Accounting Review, 49(2), 162-180.

Novotny-Farkas, Z. (2016) The interaction of the IFRS 9 expected loss approach with supervisory rules and implications for financial stability. Accounting in Europe, 13(2), 197-227.

Ozili, P. \& Outa, E. (2017). Bank loan loss provisions research: A review. Borsa Instanbul Review, 17(3), 144-163.

Ozili, P. \& Arun, T. (2018). Income smoothing among European systemic and non-systemic banks. The British Accounting Review, 50(5), 539-558. 
Pinto, I. \& Picoto, W. (2018). Earnings and capital management in European banks - Combining a multivariate regression with a qualitative comparative analysis. Journal of Business Research, 89, 258-264.

Roodman, D. (2009). How to do xtabond2: An introduction to difference and system GMM in Stata. Stata Journal, 9(1), 86-136.
Stephanou, C. (2010). Rethinking market discipline in banking: Lessons from the financial crisis' (Working paper No. 5227), The World Banks. Retrieved from file://C:/ Users/inespinto/Downloads/SSRN-id1565988.pdf

Wahlen, J. (1994). The nature of information in commercial bank loan loss disclosures Accounting Review, 69(3), 455-478. 
Disclosures under IFRS 7

Disclose/Do not disclose

The carrying amount of loans and receivables, either on the balance sheet or in the notes $(\$ 8)$

$1 / 0$

Reconciliation of changes in the allowance account, if applicable, for credit losses during the period for

$1 / 0$

each class of financial assets $(\$ 16)$

The amount of any impairment loss for each class of financial asset (\$20)

$1 / 0$

Analysis of the age of financial assets that are past due as of the reporting date but not impaired, by class of

$1 / 0$

financial asset (\$37)

Analysis of financial assets that are individually determined to be impaired on the reporting date (\$37)

$1 / 0$

Factors the entity considered in determining that they are impaired (\$37)

$1 / 0$

The criteria the entity uses to determine that there is objective evidence that an impairment loss has occured (B5)

Disclosures under Pillar 3

Disclose/Do not disclose

Collective and specific impairment losses

$1 / 0$

Doubtful loans

$1 / 0$

Forbearance

$1 / 0$

Impairment losses on loans

$1 / 0$

Nonperforming loans

$1 / 0$

Past due $1 / 0$

Appendix B - Variable Definitions

\begin{tabular}{|c|c|}
\hline Variables & Definition \\
\hline $\begin{array}{l}\text { TOTALINDEX, } \\
\text { PILLAR3INDEX, } \\
\text { IFRS7INDEX }\end{array}$ & $\begin{array}{l}\text { Self-constructed disclosure index that measures a bank's compliance with both IFRS } 7 \text { and Pillar 3, with } \\
\text { Pillar 3, or with IFRS 7, respectively. See Appendix A. }\end{array}$ \\
\hline SPOWER & $\begin{array}{l}\text { Index based on the measure of supervisory power developed by Barth et al. (2013), which ranges from } 0 \\
\text { to } 17 \text { based on the World Bank Database } 2012 \text { survey on bank regulation and supervision. }\end{array}$ \\
\hline LLP & Ratio of LLPs (loan loss provisions) to total loans. \\
\hline EBT & Ratio of earnings before taxes and LLPs to total assets. \\
\hline TIER 1 & Tier I capital. \\
\hline NPL & Ratio of nonperforming loans to total assets. \\
\hline LOANS & Ratio of customers loans to assets. \\
\hline$\triangle \mathrm{LOANS}$ & Loan growth in year $\mathrm{t}$. \\
\hline SIZE & The natural logarithm of total assets to control for bank size. \\
\hline GDP & Annual growth rate of the gross domestic product for each country. \\
\hline CAP & $\begin{array}{l}\text { Ratio of actual regulatory capital (primary or Tier I capital) before loan loss reserves to the minimum } \\
\text { required regulatory capital. }\end{array}$ \\
\hline DSSM & $\begin{array}{l}\text { Dummy variable that equals one for the period between } 2014 \text { and 2015, which indicates the period after } \\
\text { the launch of the SSM: DPILLAR3AM and DIFRS7AM }\end{array}$ \\
\hline DPILLAR3AM DIFRS7AM & $\begin{array}{l}\text { Dummy variables that equal one if the company registers a PILLAR3 or IFRS7 score above the sample } \\
\text { median of the PILLAR3 and IFRS7 indexes, respectively. }\end{array}$ \\
\hline
\end{tabular}




\section{Authors:}

1. Daniela Albuquerque, Master, ISEG - Lisbon School of Economics \& Management, University of Lisbon, Lisbon, Portugal.

E-mail: daniela.albuquerque@aln.iseg.ulisboa.pt

ORCID

(D) 0000-0001-7424-3978

2. Ana Isabel Morais, PhD, Advance/CSG, ISEG - Lisbon School of Economics \& Management, University of Lisbon, Lisbon, Portugal.

E-mail: anamorais@iseg.ulisboa.pt

ORCID

(i) 0000-0001-7251-6418

3. Inês Pinto, PhD, Advance/CSG, ISEG - Lisbon School of Economics \& Management, University of Lisbon, Lisbon, Portugal.

E-mail: inespinto@iseg.ulisboa.pt

ORCID

(D) $0000-0001-5535-914 \mathrm{X}$

\section{Contribution of each author}

\begin{tabular}{lccc}
\multicolumn{1}{c}{ Contribution } & $\begin{array}{c}\text { Daniela } \\
\text { Albuquerque }\end{array}$ & Ana Morais & Inês Pinto \\
\hline 1. Definition of research problem & $\sqrt{ }$ & $\sqrt{ }$ & $\sqrt{ }$ \\
2. Development of hypotheses or research questions (empirical studies) & $\sqrt{ }$ & $\sqrt{ }$ \\
3. Development of theoretical propositions (theoretical work) & & $\sqrt{ }$ \\
4. Theoretical foundation/literature review & $\sqrt{ }$ & $\sqrt{ }$ \\
5. Definition of methodological procedures & $\sqrt{ }$ & $\sqrt{ }$ \\
6. Data collection & $\sqrt{ }$ & $\sqrt{ }$ \\
7. Statistical analysis & $\sqrt{ }$ \\
8. Analysis and interpretation of data & $\sqrt{ }$ \\
9. Critical revision of the manuscript & $\sqrt{ }$ \\
10. Manuscript writing & & $\sqrt{ }$ \\
11. Other (please specify which) & & & \\
\hline
\end{tabular}

